\title{
THE EARLY HOMES AND HOME-MAKERS OF IOWA.
}

BY CHARLES A. WHITE, M. D., LL. D.

The class of people who seek to occupy a frontier region is largely determined by the character of its known resources; and the personal character of the people who are first attracted to, and permanently occupy, such a region naturally produces a strong influence upon its social destiny. Iowa has been particularly fortunate in this respect for, at the time it first became known to white men, its most obvious resource, the fbundantly fertile soil, made it especially attractive as a prospective land of homes; and the immigrants thus attracted were worthy and intelligent families.

The migration of those families is noteworthy as having been, not an expatriate, but a convergent, intrapatriate, movement, and for the freedom of its leading incentive from influences which have often impelled communities to self exile. They were already American citizens and therefore speedily blended into a new body politic in harmony with American ideas. They were under no leadership, and needed none, for their own sense of right ruled them in the pursuit of a common purpose. They were not irreligious, but were not dominated by any common religious belief. They were not escaping from oppression, for when their migration began they were all living under laws which they approved and among people with whom they affiliated. They were not communists of any kind, but a multitude of families gathering from various parts of their country to another part of the same with the leading purpose of establishing new and independent homes. They received no subsidiary help from any source, but each family paid its way from its own frugal savings. They were all poor, as wealth is now reckoned, and took upon themselves the hardships of frontier life to better their own condition and to make future provision for their children. 
They were without experience in the conduct of public affiiirs, and yet they acted with remarkable foresight in providing for the public good, and thus became the real founders of our State.

My chief object in preparing this article is to record a tribute of respect to the memory of those early home-makers of. Iowa, and to show their remarkable mastery of new conditions, both physical and economic. For this purpose, while embodying appropriate references to public records, I have chosen the homely form of personal narrative, and based it mainly upon facts which I observed in my boyhood and upon knowledge of the significance of those facts since acquired. That is to say, I was a boy at Burlington among those early settlers of the then new Territory of Iowa and grew up to citizenship there among their sons. My narrative will refer only to the people who took part in that migratory movement toward Iowa which was in progress from the spring of $\mathbf{1 8 3 6}$ to the autumn of 1841 , inclusive. It is limited to that period because those immigrants then encountered certain economic conditions of which I wish to make special mention, which ceased to exist at the last named date, and which were not fully developed among the comparatively few people who settled upon Iowa soil prior to 1836. Particular reference is made to the region round about Burlington because it was there that my observations were made.

The migratory movement which took place within the period just mentioned was an annually increasing one, for information of the new opportunity to obtain fertile lands at low prices became more and more widely circulated among the people. At that time there were no railroads west of the Atlantic states and therefore immigration could reach Iowa in only two ways. One was by steamboat on the Mississippi, and the other by wagon over common roads or even in some part over trackless country. The great river and the com-. mon roads were also the only thoroughfares by which merchandise could be received and products exported. My ob- 
servation of this migratory movement began in 1838, the year in which Iowa, by an act of Congress, was removed from the jurisdiction of Wisconsin Territory and given a separate territorial government. My father's family then settled at Burlington, to which point we found a strong tide of immigration converging. I therefore witnessed the arrival of great numbers of future citizens and became familiar with the conditions which they encountered in both town and country.

The immigrants who journeyed by way of the river came from various, and often distant, parts of our country and much the greater part of them settled in the towns, of which Burlington was the chief. As the town population increased it embraced the usual proportion of men in the various walks of life, but the earlier comers were mostly traders, mechanics and speculators. The first brought goods suitable to frontier trade, the second their tools and personal effects, and the third came supplied with ready money with which they hoped to enrich themselves by taking advantage of the settlers' needs. The first and second were promoters of the good of the infant community, but the third for a time gave promise of being a disturbing element in it because of their antagonistic and non-producing position.

The Wisconsin forests had not yet begun to supply the great Upper Mississippi Valley with pine lumber and Burlington's first supply of that necessary building material came by steamboat from that part of the Allegheny valley which, stripped of its primeval pines has since become a portion of the great Pennsylvania oil region. The neighboring forests furnished an abundance of hard wood for common lumber; limestone abounded in all the bluffs; the drift subsoil of the uplands furnished an unlimited supply of good brick clay, and the near-by river sand-bars were inexhaustible. With these materials at hand and the labor of the immigrant mechanics Burlington grew rapidly, homes, business houses and mills were established and the citizens, though 
lacking much of what we now call comfort, were soon in possession of all the actual necessaries of life.

The wagons by which the overland immigrants came were usually of the common two-horse farm wagon kind, with canvas cover to protect them from sun and rain. They depended upon no hostelries but carried with them their camping. utensils and daily subsistence and made their noon rests and nightly camps by the wayside. They came not only from the older settled portions of the adjacent state of Illinois, but great numbers came from Indiana, Ohio and Kentucky. Those coming the greater distances were sometimes one or two months on the journey, for the loamy soil of the roads made traveling slow although the wagons were seldom heavily loaded. The gateways by which they entered Iowa were the ferries across the Mississippi at the river towns, and they came in such numbers that large encampments of them often gathered upon the eastern bank of the river, waiting their turn to be ferried across. The turn of each wagon for ferriage was claimed in the order of its arrival at the encampment and, as a rule, it was scrupulously conceded. Contentions for precedence rarely occurred although even a few hours' delay in crossing the river often lost a good choice of a claim.

I often visited the encampments opposite Burlington and with boyish inquisitiveness noted the outfits and personnel of the travelers. It was even more apparent among these overland immigrants than among those who came by way of the river that the family was the unit of this remarkable migration. So far as I could learn, no person in all that multitude traveled alone, or unattached to a family; and of the very few unmarried men among them each was usually, if not in every case, a member or a near relative of the family to which he was attached. Healthy vigor and a readiness to. meet emergencies were apparent in every face and shown in every action.

Some of the families, especially if they were large, had. 
two wagons and one or two led horses, or even a cow, and rarely a small tent, but these were the well-to-do. The average immigrant family was small and comparatively young; and they bronght in their one wagon all their belongings, including the implements by the use of which they were to start their new homes. Of such implements the following. few alone often served their purpose for a beginning, namely: a plow, log-chain and shovel, an axe, a froe and an inch anger. These overland immigrants almost invariably settled upon farming lands and made no stop in the towns except to procure supplies.

Naturally the inhabitants of the towns took the leading part in public affairs, but the first establishment of homes throughout the land was so important in its effects npon the then future commonwealth that I am disposed to speak even more minutely of the acts of the country settlers than of those of the people who settled in the towns. Upon reaching the western bank of the river they started out in search of unclaimed lands, which they then required should be at least in part timber land, their preference being for prairie and timber land adjoining. They were guided by the surveyors' marks upon trees and stakes, which they well understood, and by information obtained from settlers who had preceded them. Such information was freely given by the setthers to one another, not only from honest impulse but because they desired neighbors who had purposes in life similar to their own.

It is easy to understand how the comparatively well-to-do family, with stalwart and helpful sons, could soon build for themselves a satisfactory house from their forest trees and a few materials obtained from the town; but the following is no imaginary description of the manner in which the head of a small family with perhaps less than the average means at his disposal, soon provided a humble home by use of the few implements which have been mentioned and the help of his willing wife. Upon making their selection of land the 
family lived for the short time as they had done on their journey, with only their wagon for shelter, but they proceeded at once to build a house if, indeed, they did not first build at least a temporary shelter for their faithful friends, the horses. Their building material was all at hand, mainly in the growing trees, for these immigrants did not build sod houses like those of the later prairie settlers.

With the axe they felled and fitted house-logs, and with the froe they split the clap-boards for the roof and large splints for the door. The logs, each noosed at the end by the logchain, were dragged to the building spot by the horses, and there quickly built up into four house-walls with two gables. From gable to gable supporting roof-logs were laid and the clap-boards laid on these like long shingles. The latter were beld in place by weight-poles laid upon them over, and parallel with, the roof-logs, the whole, including the logs of the gables being secured by long wooden pins driven into auger holes. Thus the sheltering roof was made and the house took form. The door, with its large cleat hinges, was made and secured with the same tools. There was no sound of hammering of nails or rasping of the saw, for of these they had none; and when the spaces between the logs were filled with large chips and daubed with clay, a rude fireplace erected at one end, and the clay floor had been beaten hard and smooth, their first house was built 'and their Iowa home established. This was certainly the rudest and simplest kind of a home, but it was their own so far as any effort could then make it, and they gradually improved it by adding a better door made of sawed boards, a puncheon floor and a couple of windows. Ere long a good hewed $\log$ house received the family, but not until they had, by the use of the few implements brought with them in their wagon, cleared and fenced their fields and raised their first crops.

The foregoing paragraphs indicate the leading physical conditions which were encountered by the early Iowa homemakers and, to some extent, the manner in which they met 
them. The following paragraphs indicate the economic conditions to which I have before referred, which now appear almost as strange to us as they then were to those who met them, and show that they dealt no less effectively with these conditions than they did with the others.

Upon the extinguishment of the Indian title to eastern Iowa, Congress, in an agrarian law, ordered the survey of the lands by the usual system, dividing them into townships, sections, and parts of sections. When this was done they were declared open for settlement, which declaration was a virtual invitation to settlers to occupy them. In 1836 the town site of Burlington was also ordered to be surveyed, and its lots were likewise opened for settlement or claim. At the same time eastern Iowa was divided into two land districts, the Burlington and the Dubuque, and a land office established for each at the towns respectively named. The busi. ness of each land office was managed by two officers, a Register and Receiver. The lands and lots were ordered to be :sold to the highest bidder above the minimum price of a dollar and a quarter an acre for lands and five dollars each for lots in Burlington. One duty of the Register was to act as auctioneer, and of the Receiver to take the money from purchasers and issue certificates of purchase. Payment was required to be immediate and in either gold or silver. No provision was made for the sale of lands or lots in any other than the prescribed manner, and the first of the ordered sales did not take place until November, 1838, more than two years after the land offices were ordered to be established. Moreover, no person was given any legal right of priority of purchase of the land upon which he settled, however long or indisputable may have been his priority of occupancy or the extent of his improvements; for the first general pre-emption law was not enacted by Congress until 1841, nor the first general homestead law until a still later date.

The competitive phase of those prescribed conditions of isale was in strict accordance with the unsual custom of competi- 
tion in trade, but the contingency of any advance in price above the minimum proved unmistakably to be against public policy. In the light of subsequent events it now seems strange that Congress did not enact a general pre-emption law in favor of all actual settlers when, or even before, the Iowa. lands were ordered to be surveyed, especially as limited preemption laws had previously been enacted. Even at the beginning of the migratory movement toward Iowa the necessity for such a law was so evident that every immigrant seems to have been impressed with the belief that, notwith. standing the literal terms of the agrarian law then in force, practical pre-emption would be established by the settlers. themselves and that they, occupying the lands by virtual invitation of the government, would obtain them at the minimum price. They knew that unless the right of priority of purchase was asserted and maintained the coming land sales. would be scenes of riot and confusion, and that the "land sharks," as speculators were then called, would overbid them and deprive them of the homes which they might provide for their families in anticipation of purchase. Therefore, long before the date of the first land sale was fixed they banded together for mutual protection. So effectively did they act. in this respect that the speculators' capital was soon turned largely to legitimate trade, the squatters upon farming lands. went confidently forward with their improvements, lands and town lots were freely bought and sold by a provisional system of transfer, and business progressed as in settled com. munities. By the autumn of 1838 all the lots in Burlington. were claimed and all the land within several miles of the town was occupied by settlers, many of whom had large fields under cultivation. Hundreds of houses were built and various kinds of business prosperously established in the town, which had then assumed the name of a city and was. governed by a mayor and a board of aldermen. It was also. the seat of the new territorial government, but not an acre of that farming land nor one of those town lots was yet legally owned by any individual. 
The provisional system of real estate transfer just referred to was early established as a necessary organic featureof the forming community. Conveyances were made by a form of quit-claim deed, usually called "squatters' title", and a public record was established for the same. Real estate was thus bought and sold with the same formal regularity that now prevails, but the sales were always made with the understanding that the holder of the property at the time of the approaching sale by the government should pay its stipulated price in addition to what had been paid for squatters' title. That is, the settlers fully recognized the fact that legal title could be obtained only by government sale, and no attempt was made to substitute squatters' title for it except provisionally. The price demanded and paid for the provisional title represented the asserted right of priority of purchase from the government, the appreciation in value of the property caused by favorable location and increasing demand, and the improvements made upon it; an aggregate of values which was often many times greater in amount than the government price. The records of those provisional transfers of real estate not having been either directly or indirectly authorized by any legislative action have doubtless not been preserved among the public archives.

The chief agency of the agreement for mutual protection and the execution of the provisional system of real estate transfer was an organization called the Squatters' Club, which had its headquarters at Burlington. Every proved holder of a claim upon government land or a town lot was elegible to membership whether he was the original squatter upon his claim or had purchased it from one. The club made regulations which had all the force of laws because the members yielded willing obedience; and it also acted as arbiter in such disputes as might arise between members concerning claims upon other than their already recorded parcels. The nembers were pledged to protect one another in the tenure of their approved claims, in the transfer of the 
same if they should desire to sell, and against overbidding at the approaching government sale. They also protected one another, as far as possible, in those cases of ruinously extortionate interest which was charged by the "land sharks" to every poor squatter who had to borrow money to eke out the payment of government price for his land. But most of these cases could not be remedied, and the squatter lost his claim or sold it at a sacrifice to obtain enough money to start again as an emigrant and make a new claim farther west. I do not certainly know the date of organization of the club, but I am confident it was not later than early autumn of 1836. My father became a member of it in 1838 , he having bought a squatter's claim to eighty acres of land near Burlington and a building lot in the town; and many members of the club thus became personally known to me. He once admitted to me that the club was a secret society, and I have no doubt that their compact was confirmed by solemn oath. That they all believed a secret compact to be necessary in their case is indicated by the fact that at least some of the active parties to it had been conscientious members of the anti-masonic political party whose brief existence had then only recently ended.

The crucial test of the squatters' compact was to come at the time of the government land sales, and it did come then. The club prepared' an engrossed copy of its list of members with the descriptive formula of' each member's claim opposite his name. They then appointed a public bidder who should, with this list in hand, in the presence of the settlers assembled at the sale, bid off each parcel or lot in the name of its recognized claimant the instant it was offered by the Register. No other bids were to be allowed, and even the claimant himself, if he were present, was required to remain silent. I did not witness the sale which was held at Burlington in November, 1838, which was the first sale of public lands held in Iowa, but I was present at the second one held there a few months afterward, in 1839 . The land office then oc- 
cupied a one-story frame building, long since removed, which stood on the lot at the southeast corner of Third and Columbia streets. When the hour appointed for the sale arrived, Mr. Bernhart Henn, the Register, took his stand at an open window facing the yard within which many settlers and citizens were assembled. The club's bidder had a small stand erected outside in full view of the assembly and close to the window where the Register was standing, each having his. list before him. Those lists tallied exactly with each other because they had been carefully compared before the day of sale arrived that there might be no confusion while the sale was in progress; a fact that showed the club and government officials to have been in good and proper accord. The sale began by the Register offering a parcel of land, reciting its. well understood descriptive formula, and the instant response of the club's bidder who, in a distinct voice, named the claimant and the minimum price. The Register at once accepted the bid and the entry was checked off on both lists. As there was no waiting or invitation for higher bids the sales were rapidly and alnost perfunctorily made. Still, it. was possible for an outsider to get in a higher bid if he spoke quickly and was willing to take the risk of personal injury, which every one knew he would incur.

I was listening to the monotonous progress of the sale when a violent commotion suddenly took place near me. Some one had dared to risk an overbid, but before it was. distinctly nttered he was knocked down with hickory canes, which many of the settlers then carried, for his intention was. suspected and they were ready for him. He was not killed, but his injuries were such that he could take no further action that day, and when he recovered he did not press his. demand for government title to the land he coveted. Here was apparently a dilemma, but the case was promptly met. by the Register who ignored the outside bid and accepted that of the bidder appointed by the club. When his atten- tion was afterward called to the matter he declared that he 
heard no other bid than that of the club's bidder, and his decision was final.

That attack upon the person of a resident was, so far as I have ever learned, the only act of the home-making settlers that can be construed as luwlessness; but their moderation, even in that trying instance, is shown by the fact that they did not use deadly weapons. They were plainly under selfcontrol and had no desire to kill or to inflict great injury; but they were determined to maintain their assumed right of priority of purchase and of purchase at the minimum price. It is gratifying to remember that the justice of their cause has never been seriously questioned and that as soon as prac- . ticable Congress tacitly recognized it by the enactment, first, of a general pre-emption law, and second, of a general homestead law. The first provided the very same protection for subsequent settlers upon public lands that the early Iowa settlers were obliged to provide for themselves, and made the former minimum price the stated price. The second was even more liberal, for by its provision the public lands were not merely pre-emptible, but were given without price to permanent settlers. One cannot doubt that the course pursued by the early Iowa settlers was accepted by Congress as demonstrating the necessity for those beneficent laws which, as is now well known, became potent factors in furthering the settlement of the great public domain.

When the principal part of the lands in the region round about Burlington had been sold by the government the peculiar economic conditions which have been described ceased to exist there and the land office was removed to meet the needs of the settlers upon the westward moving frontier; and when the general pre-emption law was enacted those conditions ceased entirely. Then also the Squatters: Club disbanded, and it is to be feared that its records were soon neglected and finally destroyed. It had fully served its purpose and its members, in legal possession of their property, were living under a newly enacted territorial code of just 
laws. But the influence of the club did not stop there, for those who had so faithfully served a common cause remained fast friends to the end of their lives.

Much as this energetic people had overcome they were still confronted with unusual difficulties. Great physical obstructions lay in the way of developing necessary trade, and they were also met by a new adverse economic condition, one which followed, and was caused by, the government land sales. The money which was received for lands and town lots was promptly shipped to Washington and the whole region was drained of its specie for, as a rule, the settlers' last dollar went into the coffers of the land office. Very little good paper money was in circulation and no means were available for increasing its volume. To obtain money from abrond it was necessary to raise crops and domestic animals and to ship the products away to a market. The Mississippi river and common roads were still the only thoronghfares by which merchandise could be received and products exported. Available markets were so distant and wagon transportation so inadequate that it was comparatively little used except for inland trade. The Mississippi river was therefore the only available route for exportation, and its navigation was closed by ice three months of the year. The principal markets to which products could be shipped and from which grocery supplies, farm implements and mill machinery could be conveniently obtained were St. Louis and New Orleans: Purchases of dry goods and hardware were largely made in New York City and shipped by sen to New Orleans and thence up the Mississippi river. When merchants went east to buy gooods their journey, going and coming by way of the Mississippi and Ohio rivers, consumed nenrly or quite two months.

The delayed supply of sufficient money from exports rednced trade of all kinds to a condition of barter. Workmen exchanged their labor for food and clothing and various kinds of property. Merchants exchanged their goods for labor, 
farm products and such other obtainable property as they de: sired or could again exchange. To facilitate such exchanges. they issued numerous certificates of indebtedness for small amounts payable in goods. These, to a considerable extent served the purpose of money, but for a few kinds of goods, then called "cash articles," ready money was demanded. - Fortunately most of those articles were not real necessaries of life and the settlers generally did without them or used the smallest quantity practicable.

Because the present condition and foreign relations of our. postal system constitute one of the grandest triumphs of modern civilization, and its demands draw so lightly upon the purse, it is difficult now for one to realize that those early settlers found the postal rates and requirements then established to be an onorous addition to their already great embarrassments; but such was the case. The rate on letters to or from correspondents in the east, of half an ounce weight and written on one ${ }_{j}$ piece of paper without an envelope, was twenty-five cents; and for each additional half ounce, and also for each additional piece of paper enclosed, if detected, an additional rate of twenty-five cents was demanded. Prepayment was optional and seldom practiced, largely through fear that the letter might not reach its destination, or that the receiving postmaster might forget to stamp it prepaid. Therefore the settlers had those high rates of postage to pay on the letters they received. The system of barter then practiced in trade conld not be extended to the operations of the Post Office, and the prescribed rates were required to be paid in lawful money before delivery of the letters. So scarce was money for a time that industrious and prospectively prosperous citizens were often obliged to allow their letters to lie some days in the Post Office before they could raise the necessary coin for their redemption.

The disastrous effects of the great financial panic of 1837 were still severely felt thronghout the country, and were a further cause of embarrassment to the settlers; but all these 
adverse conditions did not stop, although they retarded, the industrial growth of the infant commonwealth. House building and other enterprises continued in the towns, much farm produce was shipped away by the merchants, food was abun. dant, and no one was necessarily idle. The farmers continued to clear and cultivate new fields, the virgin soil yielded abundantly. 'disease was not then known among their domestic animals, and their products accumulated faster than they could be advantageously disposed of to the merchants. Still, they were not behind the townspeople in making good use of their opportunities. For example, they frequently formed neigh borhood partnerships to build large, rude, covered flatboats from the wood of their forest trees, and in them shipped their surplus products to market on their own account. These bonts were manned by crews selected from among themselves and floated down the great river by its current, usually to St: Louis, but often to New Orleans. There the cargoes were sold for cash, the boats abandoned because they could not be navigated up stream, and the men returned home by steamboat as passengers. Such flatboats soon became so numerous upon the Mississippi that, having no motive power to escape collision, legal right of way was accorded them in the channel, as against steamboats, which were thus obliged to turn aside for them.

Those pioneer founders of our State performed the important acts, of which the foregoing is a very inadequate account, with vigor and discrimination, and endured with fortitude those conditions which they could not change. Possessing such traits of character, and having begun to receive considerable cash returns from exported products, they speedily brought trade to a sound financial basis and attracted investments of capital from abroad. With this turn of affairs they soon realized their ideals of home-making and inaugurated a permanent career of prosperity which has. placed Iowa in the foremost rank of progressive states.

The following brief summary may serve in some measure

VoL. IV. -13 
to emphasize the foregoing statements conceming the strange physical and economic conditions which the early settlers encountered and overcame: The migration of that people was not an exilement, nor a separation from uncongenial associations, but a wide-spread intrapatriate movement of which the family was the unit and home-making the incentive. They acted in the accord that was born of honest purpose, but without either personal or conventional leadership. They overcame great physical difficulties with the smallest possible amount of means and with the simplest appliances. Nothing was further from their intention than disregard of law, but at the outset they found themselves obliged to practically nullify a contingent provision of an act of Congress by asserting and maintaining the right of priority of purchase of the lands upon which they settled when the same should be offered for sale by the government. By this determined action they prevented merciless speculators from depriving them of their little all, which they had invested in their new homes, and demonstrated that while competition is a necessary element in ordinary business, it was against public policy as applied to the sale of the public lands to actual settlers. Foreseeing that a long time would elapse between their virtually invited occupancy of the public lands and the sale of the same by the government, they found it necessary to establish for that interim a provisional system of ownership and transfer of those lands; and they banded together to defend the titles thus assumed and transferred, as well as the right of priority of final purchase from the government. They rigidly maintained that system for more than two years, but eagerly accepted its termination as effected by the government land sales. Although successive transfers, or chains of squatters' titles, often of considerable length, were made and maintained under that provisional system during the period mentioned, those early titles are now always ignored when chains of land title are traced in that region, because sale or relinquishment by the government was the beginning of all 
legnl land title there. That provisional system of ownership and transfer of lands, to meet the requirements of homemaking and legitimate trade, while they were yet really the property of the government, the circumstances which attended its speedy establishment and rigid maintenance for more than two years, and its sudden and peaceful termination, constitute a unique and interesting stady in social economics.

Washingten, D. C., 1899.

Bones of Black Hawk.-These bones which were stolen from the grave about a year since have been recovered and are now in the Governor's office. The wampum, hat, etc., which were buried with the old Chief, have been returned with the bones. It appears that they were taken to St. Louis and there clemed; they were then sent to Quincy to a dentist to be put up and wired previous to being sent to. the East. The dentist was cantioned not to deliver them to any one until a requisition should be made by Governor Lucas. Gov. Lucas made the necessary requisition and they were sent up a few days since by the mayor of Quincy and are now in the possession of the Governor. He has sent word to Nasheaskuk, Black Hawk:s son, or to the family, and. some of them will probably call for them in a few days. Mr. Edgerton, the phrenologist, has taken an exact drawing of the skull, which looks very natural, and has also engraved it on a reduced scile, which will shortly appear on his new chart. Destructiveness, combativeness, firmuess and philo.progenitiveness are phrenologically speaking, very strongly. developed.-Burlington Hanok-Eye, Doc. 10, 1840. 
Copyright of Annals of Iowa is the property of State of Iowa, by \& through the State Historical Society of Iowa and its content may not be copied or emailed to multiple sites or posted to a listserv without the copyright holder's express written permission. However, users may print, download, or email articles for individual use. 